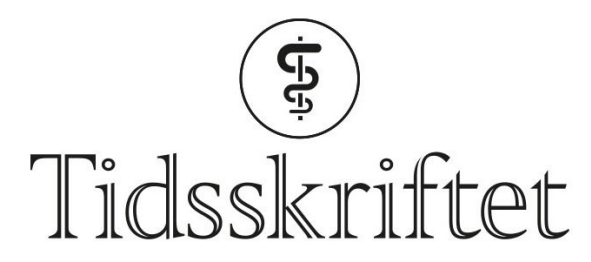

DEN NORSKE LEGEFORENING

\title{
Når legen går over grensen
}

REPORTASJE

JULIE KALVELAND

E-post: jkalveland@gmail.com

Frilansjournalist

Gro Vik Knutsen ble overrasket da hun oppdaget hvor streng Helsetilsynet er i saker der leger inngår forhold til pasienter. Studentene Nora (26) og Andreas (26) ønsker seg mer undervisning om hvilke regler som gjelder.

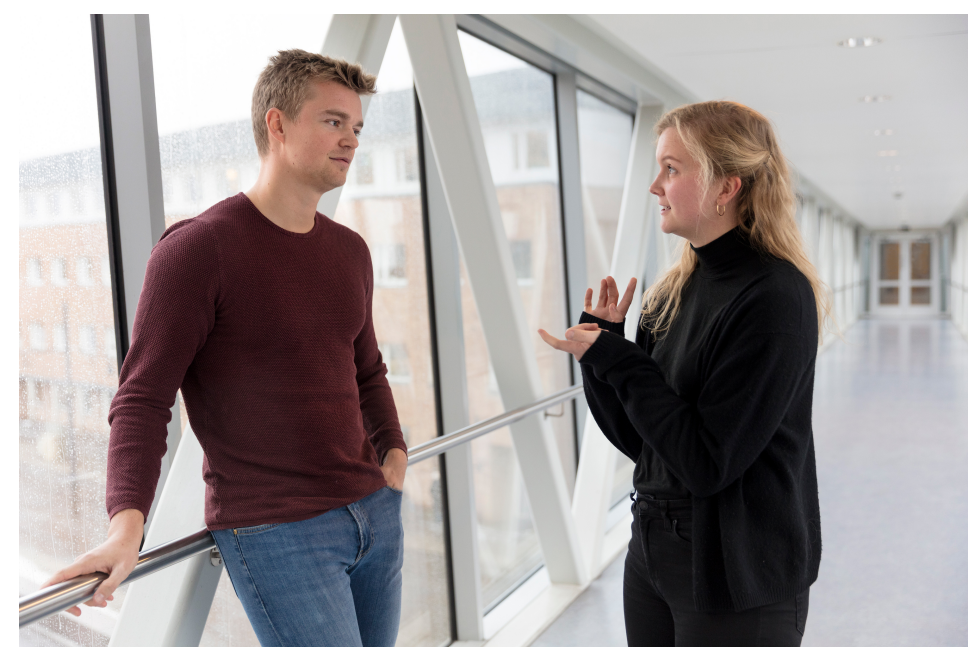

Medisinstudentene Andreas Meuche Henriksen og Nora Ruud er ikke helt sikre på hvilke regler som gjelder, men de er enige om at det ville vcert problematisk om en lege viste interesse ut over det medisinske for en pasient som vedkommende hadde hatt til behandling over lengre tid. Foto: Christian Tunge

Grove overgrepssaker og tilfeller med leger som gang på gang har tråkket over og misbrukt sin stilling, slås ofte stort opp i mediene. Få har innvendinger mot at leger som begår slike overtramp, regnes som uskikket til å være leger. Men hva med sakene hvor både lege og pasient har ønsket et forhold?

- Jeg tenker at det er ekstremt viktig at leger har en profesjonell rolle og at den er helt uforenelig med å ha et forhold til en pasient, sier Andreas Meuche Henriksen (26).

Henriksen studerer medisin på fjerde året ved Universitetet i Oslo og sitter i kantinen på Rikshospitalet klar for kollokviegruppe med medstudenter. Forhold mellom pasient og lege er ikke noe han har reflektert særlig mye over før.

Det samme gjelder medstudent Nora Ruud (26) som sitter tvers overfor ham. Men hun har gjort seg noen tanker om nærhet og distanse til pasienter. Da hun startet på studiet, var planen å bli psykiater, og hun har jobbet som pleiemedarbeider i psykiatrien. 
- Der jeg jobbet, har man for eksempel en regel om at man ikke skal legge til pasienter på Facebook. Jeg vet at det finnes slike regler mange steder, men om du jobber på en plass uten, har du kanskje ikke tenkt over dette. Hvis du da avviser noen, kan du føle deg frekk.

Les også: Hva skjer når lege og pasient forelsker seg?

\section{Ville reagert som pasient}

Nye datingmetoder som mobilappen Tinder kan også bidra til at man kan komme opp i vanskelige situasjoner, tror Ruud.

- Hva om du jobber på et lite sted hvor det ikke er mange på din alder og du bruker Tinder. Så har du undersøkt noen på sykehuset for et mindre problem, skal du da ikke få lov å ha kontakt med dem?

Verken Ruud eller Henriksen er helt sikre på hvilke regler som gjelder, men de er enige om at det ville vært problematisk om en lege viste interesse utover det medisinske for en pasient som vedkommende hadde hatt til behandling over lengre tid.

- Om jeg var pasient og matchet med legen min på en datingapp, ville jeg følt det som ubehagelig, siden denne personen kan vite mye om meg, sier Ruud.

- Ja, og du kan jo begynne å lure på om den interessen påvirket behandlingen du fikk, legger Henriksen til.

\section{Over 200 innmeldte saker}

I perioden 2007-17 behandlet Statens helsetilsyn 209 tilsynssaker om helsepersonell og seksuelle relasjoner til pasienter. Sakene, som inngår i kategorien «rollesammenblandingssaker» meldes vanligvis inn via fylkesmannen for eksempel av pasienten selv, legens arbeidsgiver eller en ny behandler. Fylkesmannen vurderer om saken bør sendes videre til Helsetilsynet.

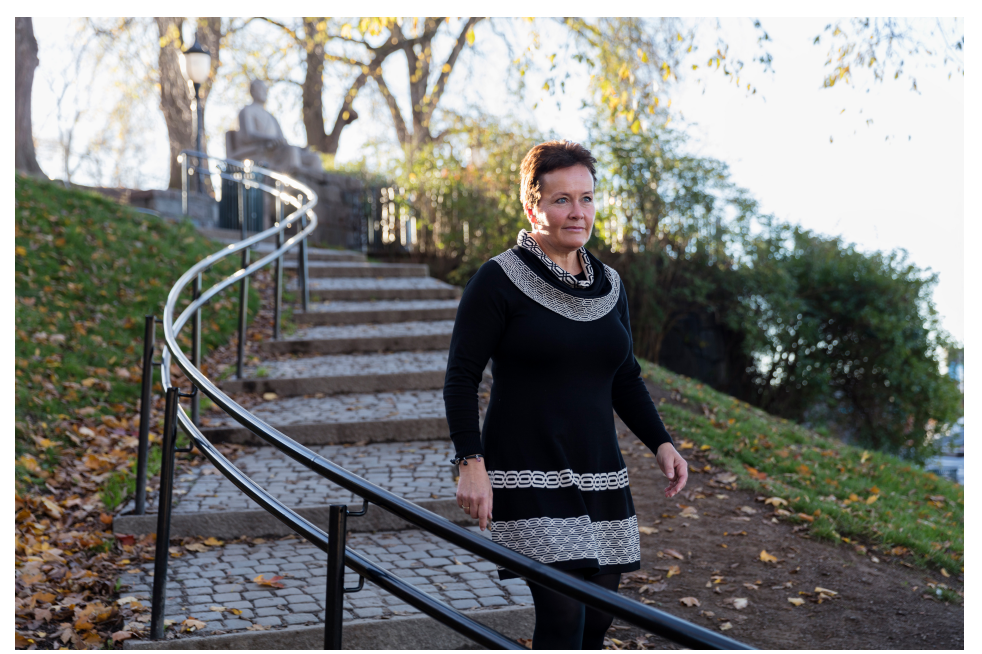

Siden hun ikke fant norsk forskningslitteratur om temaet med rollesammenblanding, bestemte geriater og tidligere saksbehandler $i$ Helsetilsynet Gro Vik Knutsen seg for å ta det opp $i$ masteroppgaven $i$ helseadministrasjon som hun nettopp hadde tatt fatt på. Foto: Christian Tunge

- De fleste saker om rollesammenblanding er så alvorlige at de blir videresendt fra fylkesmannen. Vi vurderer om det helsepersonellet har gjort strider mot regler i helsepersonelloven, sier Vigdis Malt Marøy som er fagsjef i Avdeling for kommunale helseog omsorgstjenester i Statens helsetilsyn.

I loven står det at «helsepersonell skal utføre sitt arbeid i samsvar med de krav til faglig forsvarlighet og omsorgsfull hjelp som kan forventes ut fra helsepersonellets kvalifikasjoner, arbeidets karakter og situasjonen for øvrig».

- Vi har ulike reaksjoner vi kan gi. Det mildeste er en advarsel og det strengeste er å tilbakekalle autorisasjonen, sier Marøy. 
Helsepersonell som har blitt ilagt begrensninger eller har mistet autorisasjonen, kan søke Statens helsetilsyn om å få opphevet begrensningene eller få ny autorisasjon på et senere tidspunkt.

Sakene som kommer inn til Helsetilsynet, har flere fellestrekk, ifølge Marøy.

- Med forbehold om at vi ikke har gjort en systematisk gjennomgang av alle sakene, er vårt inntrykk at flertallet er menn, selv om det er viktig å påpeke at det finnes saker med både menn og kvinner. Når det gjelder tilbakekalling av autorisasjonen, skjer det ofte når en lege eller psykolog innleder en privat relasjon til en person som har en psykisk sykdom eller rusmiddelproblem. Der ender vi ofte med en streng reaksjon, sier fagsjefen.

I over $80 \%$ av sakene mot helsepersonell som Helsetilsynet har behandlet de siste ti årene, har tilsynet konkludert med at det har blitt begått lovbrudd. I flertallet av disse sakene ble helsepersonellet fratatt autorisasjonen eller lisensen. I de få sakene der det kun er gitt en advarsel, er det snakk om mer jevnbyrdige forhold, ifølge Marøy.

- En advarselssak kan være en sak der det er innledet en relasjon, men at pasienten har gått inn i det på et likeverdig nivå med legen. Med advarselen vil man likevel vise at behandler skal være bevisst sin egen rolle.

Les også: Kan lege og pasient ha kontakt etter at behandlingen er avsluttet?

\section{Ser strengt på forhold til pasienter}

Blant helsepersonellet som har blitt innrapportert til Statens helsetilsyn på grunn av seksuelle relasjoner til pasienter de siste ti årene, er 65 leger. Flertallet er leger i

allmennpraksis.

- Er det i noe tilfelle «lov» for en lege å innlede et forhold til en pasient?

- Statens helsetilsyn ser strengt på dette. Pågående behandlingsforhold er ikke forenlig med å inngå en privat relasjon til en pasient. Om man treffes i privat sammenheng når man bor på et mindre sted, er fastlege og ikke lenger har pasienten på sin liste, så blir det noe annet. Men det har vært saker som har blitt prøvd i klagenemnda der man har vært streng, sier Vigdis Marøy.

Hun henviser til en tidligere sak i mediene der en omsorgsarbeider i Lillehammer forelsket seg i en bruker. Saken ble første gang dekket av NRK i 2014. Ifølge NRK Hedmark og Oppland ga omsorgsarbeideren beskjed til arbeidsgiver da hun og brukeren «skjønte at det de hadde sammen trolig var mer enn bare vennskap», og hun byttet arbeidslag slik at hun ikke lenger jobbet sammen med ham. Kommunen rapporterte forholdet til fylkesmannen, som rapporterte videre til Helsetilsynet. Helsetilsynet vedtok i denne saken en begrensning i autorisasjonen til omsorgsarbeideren, med vilkår om blant annet faglig og personlig veiledning. Vedtaket ble fastholdt etter klage. Tre år senere, etter søknad med ny dokumentasjon, fikk omsorgsarbeideren begrensningene opphevet.

\section{Ble overrasket i ny jobb}

«Streng» er et ord som går igjen i beskrivelsene av Helsetilsynets vurderinger. På en kafé i Oslo sentrum sitter lege Gro Vik Knutsen. Også hun bruker samme beskrivelse - «strengt» Veldig rart er det ikke, siden hun har bakgrunn som saksbehandler i Helsetilsynet, men hun har også et tillegg: «overraskende strengt».

Fra Knutsen var ferdigutdannet i 1995 og frem til 2011 jobbet hun ved Bærum sykehus, etter hvert som geriater og avdelingsoverlege. Så startet hun i ny jobb som saksbehandler i Helsetilsynet. Som et ledd i opplæringen ble den erfarne legen satt til å lese seg opp på tidligere vurderinger som tilsynet hadde gjort. En spesiell type saker utmerket seg.

- At det gikk an å innlede et forhold til en pasient, var noe jeg selv aldri hadde tenkt på før, selv etter ha vært lege i klinisk praksis i mange år, sier hun i dag. 
Men det var ikke bare legenes handlinger som gjorde inntrykk.

- Det overrasket meg hvor streng Helsetilsynet var i disse sakene og hvor lite som skulle til for å miste autorisasjonen.

For nykomlingen Knutsen var det tydelig at det var stor variasjon i tilsynssakene.

- Noen saker var ganske opplagte, mens andre ikke var det. Det ryster vel de fleste av oss om en psykiater utvikler et seksualisert forhold til en sårbar pasient. Men i andre saker kan det være snakk om et pasient-lege-forhold som ligger tilbake i tid, personene møtes igjen og det utvikler seg en intim relasjon over tid. I begge tilfellene risikerte legen å miste autorisasjonen, forklarer Knutsen, men legger til en nokså overraskende opplysning:

- Tidsaspektet var ikke en formildende omstendighet. - Tid kan tillegges vekt, men det må ikke, sier hun. - Det er ingen automatikk i at tid er formildende.

\section{Allmennleger og sykehusleger vurderte ulikt}

Knutsen begynte å lure på hvor mye andre leger visste om reglene. Siden hun ikke fant norsk forskningslitteratur om temaet, bestemte hun seg for å ta det opp i masteroppgaven i helseadministrasjon som hun nettopp hadde tatt fatt på.

I 2012 gjennomførte Gro Vik Knutsen fokusgruppeintervjuer med 12 leger. Hun intervjuet to grupper med seks allmennleger og seks sykehusleger. Begge gruppene besto av leger i ulike aldre, men som hadde kjent hverandre over lengre tid. Knutsen valgte gruppene fordi hun mente at leger som kjente hverandre på forhånd, ville kunne snakke friere om sine refleksjoner rundt det tabubelagte temaet. Knutsen valgte bevisst å ikke intervjue psykiatere, fordi disse gjennomgår mye opplæring i rolleavklaring og fort ville kunne svare i tråd med forventningene til dem.

- Alle jeg intervjuet var opptatt av at det er viktig å ikke misbruke rollen som lege, sier Knutsen.

Hun understreker at hun er forsiktig med å generalisere ut ifra funnene, ettersom studien er liten, men at hun så noen forskjeller i utvalget sitt. Legene Knutsen intervjuet fikk forelagt fire eksempler på saker Helsetilsynet hadde behandlet i de foregående årene.

- Sykehuslegene diskuterte i liten grad hvilken diagnose pasienten hadde i eksemplene. Allmennlegene satte mer spørsmålstegn ved om diagnosen var riktig, for eksempel om «manipulerende trekk» var en del av en diagnose eller et personlighetstrekk. Det kom frem at en del av allmennlegene var opptatt av at også pasientene har et ansvar for at det ikke oppstår en intim relasjon. Sykehuslegene var mer absolutte og mente at det var legens fulle ansvar, sier Knutsen.

Hun tror forskjellen kan komme av at allmennlegene jobbere tettere med pasientene og har en samværsform som ligner private relasjoner i større grad enn relasjonen sykehuslegene har til sine pasienter.

\section{Trodde det fantes en «karenstid»}

Flere av legene var, som Knutsen, overrasket over at tid ikke spilte en større rolle.

- Noen mente at det gikk greit om det hadde gått noen år siden legen hadde pasienten til behandling, og noen så for seg at det var en «karenstid» på 2-3 år. Man kunne få inntrykk av at Legeforeningen hadde gitt råd om dette. Men da jeg oppsøkte Legeforeningen i etterkant av fokusgruppeintervjuene, var juristene der veldig tydelige på at man ikke gir denne typen råd, sier hun.

Legene Knutsen intervjuet gjorde vurderinger av hvilken reaksjon de trodde legen ville få $\mathrm{i}$ de fire eksempelsakene. Når det gjaldt reaksjoner i disse sakene, "traff» legene i studien godt.

- Sykehuslegene falt ned på samme beslutning som Helsetilsynet. Allmennlegene avvek litt, 
men jeg konkluderer med at legenes oppfatning stemmer overens med Helsetilsynets oppfatning i disse sakene.

Studien kunne likevel tyde på at det var få som visste hvordan Helsetilsynet vurderer saker.

- Mange leger vet at man kan miste autorisasjonen hvis man misbruker rusmidler, men få av de jeg snakket med visste at man også kunne miste autorisasjonen fordi man hadde et forhold til en pasient. Mange av legene trodde at man bare fikk en advarsel i denne type saker. Det var også få som hadde fått opplæring i temaet. De kunne ikke huske å ha hørt noe om dette i medisinutdanningen eller i videreutdanningen, sier Knutsen.

På spørsmål fra Tidsskriftet om det finnes en «karenstid» oppgir Helsetilsynet at «hver tilsynssak vurderes individuelt med momentene som foreligger i den enkelte sak. Ansvaret for å ikke blande sammen sin rolle som behandlende lege og privatperson ligger først og fremst hos legen».

\section{Opplæring tidlig i studieløpet}

Studentene på Rikshospitalet er ikke overrasket over å få høre at mange mister autorisasjonen på grunn av forhold til pasienter. Hvor grensen går, er de imidlertid mindre sikre på.

- Jeg tror at dette temaet er veldig fjernt for mange studenter, sier Andreas Meuche Henriksen.

Ingen av studentene kan huske å ha lært noe om rollesammenblanding til nå på studiet, men de skulle gjerne visst mer.

- Vi har mange atferdsfag og mye kommunikasjonsundervisning hvor vi driver med rollespill. Dette kunne kanskje også passet å ta opp på den måten, sier Henriksen.

Studentene tror at rollesammenblanding blir et tema i psykiatribolken de skal ha neste år, men mener at de gjerne skulle hatt undervisning i temaet fra de starter med pasientkontakt.

- Dette burde jo egentlig vært tatt opp når vi er ute i fastlegepraksis. Det ville vært en gyllen mulighet, sier Nora Ruud.

\section{Håper \#metoo kan øke bevisstheten}

For Gro Vik Knutsen består hverdagen i dag av en ny jobb i Helse Sør- $\emptyset$ st hvor hun jobber med helt andre tema. Hun har med tiden gått fra å være overrasket over vurderingene til Statens helsetilsyn til å definere seg selv som «streng»:

- Det er noe med at du jobber deg inn i en problemstilling. Jeg har forstått mer av kompleksiteten og hvilke traumer det utsetter pasienten for. Det kan føles fint ut der og da, men når et forhold går i stykker, kan du plutselig se at du var i en sårbar fase og at behandleren din benyttet det til å inngå et forhold med deg, sier hun.

\section{I perioden 2007-17}

- 44 leger har mistet autorisasjonen etter brudd på reglene om seksuelle relasjoner

- Én lege har fått autorisasjonen suspendert på ubestemt tid

- Seks ganger har leger blitt ilagt begrensninger i autorisasjonen. To leger har blitt ilagt begrensninger i to omganger

- Fire leger har fått en advarsel. En av disse fikk senere autorisasjonen tilbakekalt 
Knutsen mener det er viktig at man setter klare grenser.

- Pasientene skal være trygge på relasjonen til sin behandler. Da er det viktig at man rendyrker legerollen.

Knutsen tror at sakene som meldes inn til Helsetilsynet i realiteten kan være toppen av et isfjell og at det er behov for at leger er mer bevisst på sin rolle. Der kan også \#metoodebatten hjelpe, tror hun.

- Vi har nylig vært igjennom en viktig debatt om \#metoo og skjevhet i maktforhold. Jeg tror den kampanjen kan gjøre at leger og helsepersonell generelt blir mer bevisst på at man ikke må bruke rollen som profesjonell behandler til å inngå intime relasjoner, sier hun, før hun tenker seg om og legger til:

- Man kan iallfall håpe.

Publisert: 5. desember 2018. Tidsskr Nor Legeforen. DOI:10.4045/tidsskr.18.ogo9

(C) Tidsskrift for Den norske legeforening 2020. Lastet ned fra tidsskriftet.no 